\title{
EFFICIENCY MACHINING PROGRAM BY COMPARING NUMERICAL CODE CONTROL MADE FROM CATIA AND MASTERCAM
}

\author{
Eko Muh. Widodo*), Tuessi Ari Purnomo, Lilik Suwito \\ Departement of Industrial Engineering, Faculty Engineering, University Muhammadiyah of \\ Magelang
}

(Received: May 26, 2017/Accepted: September 30, 2017)

\begin{abstract}
Tooling department is the department which is engaged in manufacturing of dies that is making a molding tool to create a component / pressed parts made in accordance with the desired design and processed on a press machine, dies ordered from the customer is the sole agent for the brand (car manufacturers). Manufacturing of dies including project work, one of the project, namely the project of manufacturing dies 640A dies drawing part number 53711/12. The project, which is now run already efficient, but to improve services to car manufacturers and to lower the cost of manufacturing the dies on the project it is necessary to compare the code in order to produce a numerical control machining program efficiency. The measures focused on the machining process because there are inefficiencies in the machining program code. Therefore, it will do the analysis of the technical terms in order to get an efficient machining program, so it can reduce the operational costs of the project 640A 53711/12 drawing process. Numerical control (NC) or machining of the program comes from Catia software and MASTERCAM. Numerical control resulting from more effective MASTERCAM machining program for the data that appears in accordance with the dies face (G01: data flat, G02 / G03: Data radius) and therefore contributes to machining machine age. The results of the analysis techniques that select programming from the machining MASTERCAM because it is more effective and calculate the percentage efficiency of the machining program MASTERCAM when compared with catia amounted to $49.36 \%$.
\end{abstract}

Keywords: tooling, pressed parts, drawing dies, ball nose

\section{Introduction}

The development of the automotive industry in Indonesia which shows the enhancer gives the place to the ATPM (sole agent brand holder) to compete in the market, especially the car manufacturers. This can be seen from the increasingly diverse brands and types of cars in Indonesia. With the competition of the automotive industry will affect the ATPM partners in the automotive component industry competition is competing to get the demand for tooling / dies project to produce car components. PT. Mekar Armada Jaya Magelang is one of ATPM's partner which is engaged in Autobody Manufacturing, Dies/ Tool Manufacturing and Pressed Part Component with Dies/ Tool, Precision Jigs, and Checking Fixture (C/ F) products. For Pressed Part Component has gained confidence from ATPM in the manufacture of car components such as PT. Astra Daihatsu Motor (ADM), PT. Toyota Motor Manufacturing Indonesia

\footnotetext{
*) Penulis Korespondensi.

email: ekomuhwidodo@gmail.com
}

(TMMIN), PT. Honda Prospect Motor (HPM), PT. Suzuki Indomobil Indonesia, PT. Mitsubishi Kramayuda Motors And Manufacturing (MKM), PT. Nissan Motor Indonesia.

With the competition between the sole agent of the brand holder, PT. Mekar Armada Jaya always strives to perform the activities of time control, quality control, cost control, machine control, and labor control and company policy in tooling/ dies making. These activities are conducted so that companies gain the trust of ATPM to maintain and expand the market share owned by the company. Tooling/ dies is a printing tool for making a component/ pressed part made in accordance with the desired design and processed over the press machine (Masaya, 2011).

Dies are usually used for the formation or construction of thin plates.Machining is a manufacturing process in which the shape of the geometry of the workpiece is changed by removing more material. By controlling the workings of the tool on the workpiece the desired geometry shapes are formed (Mokh \& Slamet, 1999). Machining process is in support with the program nc (numerical control) Which is produced software cad/ cam. The Dies/ 
tooling 640A project with the current 53711/12 part number is efficient, but to improve service to ATPM and to lower manufacturing costs across the project it is necessary to compare the numerical control code to produce an efficiency machining program. The move is focused on the machining process Because there is inefficiency in the code machining program. In connection with this, it will be analyzed from a technical point of view in order to get an efficient machining program, so that it can reduce operating costs on the 640A project drawing process 53711/12.

\section{Method Research}

Efficiency The meaning of efficiency can be seen from different angles. Efficiency can be defined as the ratio between output and input (Kost \& Rosenwig, 1979). There are three factors that cause efficiency, that is, if with the same input produces a larger output, smaller inputs produce the same output, and large inputs produce larger outputs.

Technical Analysis Decision-making should always start with a technical feasibility analysis, followed by an economic feasibility analysis. Problems related to technical aspects are discussions that focus more on operational functions or technical performance (Wignjosoebroto, 2006). Technical analysis of the machining program is related to the technical aspects of the machining program, the length of the machining course, the total time required for the machining dies process, the cutter load used in forming face dies / tool face, and cutter life.

Efficiency Analysis In principle, economic/ efficiency analysis will explain the principles and methods needed for decision making on matters relating to the ownership or obsolescence of the capital goods of an industry. With the same concepts and methods, this economic analysis can also be applied to take decisions on alternatives that can be taken for a particular investment. Economic analysis is applied to evaluate engineering projects that must first take into account its technical factors and further use the results of such analysis as a basis for decision making commonly called economic analysis techniques (Wignjosoebroto, 2006).

Design or proposal from engineering projects will be evaluated on the basis of technical/ physical efficiency as well as economic efficiency. Technical efficiency is generally formulated as follows (Wignjosoebroto, 2006):

Efficiency $($ technique/ physical $)=($ Output $($ physical $)) /$ (Input (physical)) x 100\%

The physical unit of output and input is measured in the resulting product. The value of technical or physical efficiency will always be $100 \%$. The closer to $100 \%$ will indicate that the physical transformation process will be more efficient. On the other hand economic efficiency is also expressed as the ratio of output per input but expressed in economic units (money). The formulation is generally as follows (Wignjosoebroto, 2006):

Efficiency $($ economy $)=($ Output $(\mathrm{Rp})) /($ Input $(\mathrm{Rp})) \mathrm{x}$ $100 \%$

Output is expressed as the value of rewards (worth) and input costs that have been issued. Both are expressed in units of money (Rp). The expected economic efficiency is $>100 \%$ so it can be stated that the process of input-output transformation has been successful economically. The efficiency or economic analysis of the machining program deals with the financial aspects or costs incurred for the machining process when the machining program is applied to 3 axis milling machines.

A. CAD/ Cam CAD/ CAM stands for Computer-

Aided Design and Computer-Aided

Manufacturing.

Computer-Aided Design (CAD) is the use of computer systems to assist in the creation, modification, analysis, or optimization of a design. Computer-Aided Manufacturing (CAM) is a manufacturing system that optimizes the ability of computer programs to translate engineering designs created by CAD so as to control the CNC (Computer Numerical Control) machine. Here is CAD/ CAM software that can control CNC machine:

a. CATIA

CATIA (Computer Aided Three Dimensional Interactive Application) is a multi-platform, CAD software that functions in designing, CAE functioning in engineering design and CAM that works for manufacturing process. This software was developed by Dassault Systemes originating from France and marketed by IBM, but unfortunately since 2008 for CATIA sales in Indonesia is done directly by Dassault Systemes through its Business Partner. With its advantages as a multiplatform software, CATIA is so pampering its users that only one software can design, analyze, and design the manufacturing process until its simulation.

b. Mastercam

Mastercam is a software used to describe or plan the process of machining virtually through a computer screen. The result of machining process planning is then used as a guideline on CNC (Computer Numerical Controlled) machine programming. Mastercam was developed in Massachusetts in 1983. The company that developed Mastercam is CNC Software, Inc. Which is one of the few oldest computer-aided design/ computer-aided manufacturing PC software developers. CNC Software, Inc. Currently located in Tolland, Connecticut. Currently, Mastercam is 
widespread and often used in both industry and education.

B. Machining Program

Machining Program or Numerical Control (NC) is a form of programmable automation where the control process uses numbers, letters, and symbols. Figures, letters, and symbols are arranged in a specific format so as to form a program of instructions for working on a particular work or workpiece (Mokh \& Slamet, 1999).

A numerical control system consists of 3 basic components:
a. Program instruction
b. Machine control unit
c. Processing equipment

The format of writing this NC program must follow a standard containing commands codes and arranged in a logical sequence. This format contains a command code that sends program information to the machine servo drive, relays, micro-switches, etc. to process the workpiece in question. The basic command code most commonly used in 3 axis milling machines is as follows.
A. G00 Rapid Positioning Motion
B. G01 Linear Interpolation Motion
C. G02 Circular Interpolation Motion CW
D. G03 Circular Interpolation Motion CCW
E. G17 Circular Motion XY Plane Selection
F. G18 Circular Motion ZX Plane Selection
G. G19 Circular Motion YZ Plane Selection
H. G20 Verify Inch Coordinate Positioning
I. G21 Verify Metric Coordinate Positioning
J. G90 Absolute Positioning Command
K. G91 Incremental Positioning Command
L. M03Spindle On, Clock wise
M. M05Spindle Stop
N. M30 Program End
O. S Spindle Speed
P. F Feed Rate Motion

The machining process that runs for making Drawing dies is conducted by custom test. Custom test is a 3-dimensional program that runs on the curve path and is projected onto the surface dies. Custom test is used for checking contur dies, setting dies, and stock casting material on dies. Cutter used in custom test program with ball nose type cutter as seen in Figure 1.

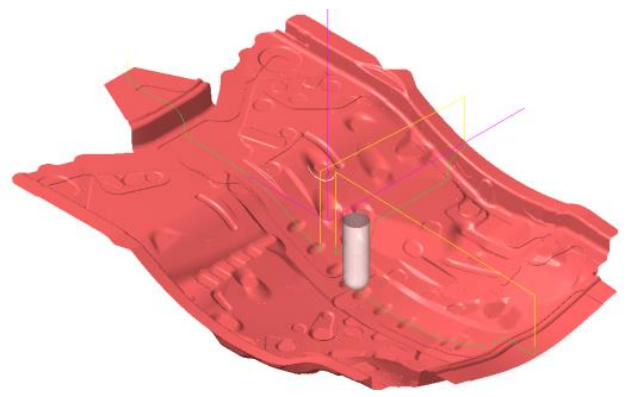

Figure 1. Custom Test a. Water Line

Water Line Water line is a 3-dimensional finishing program with track path on the extreme wall area at 610 to 900 angle. Cutter used in Water Line program with ball nose type cutter as seen in Figure 2.

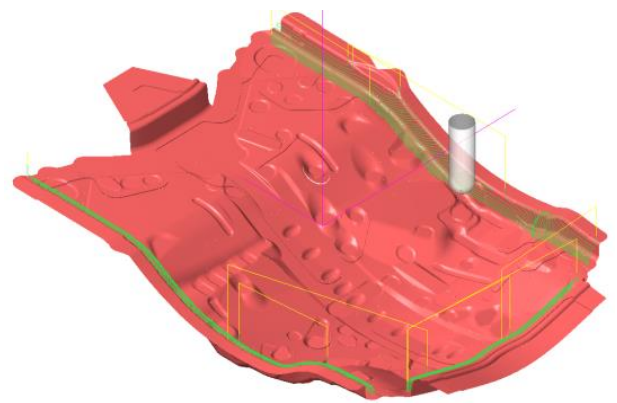

Figure 2. Water Line

b. Raster

Raster is a 3-dimensional finishing $\mathrm{nc}$ program strategy that runs on flat areas and ramps between angles of 00 to 600 . Cutter used in Raster program with ball nose type cutter as seen Figure 3.

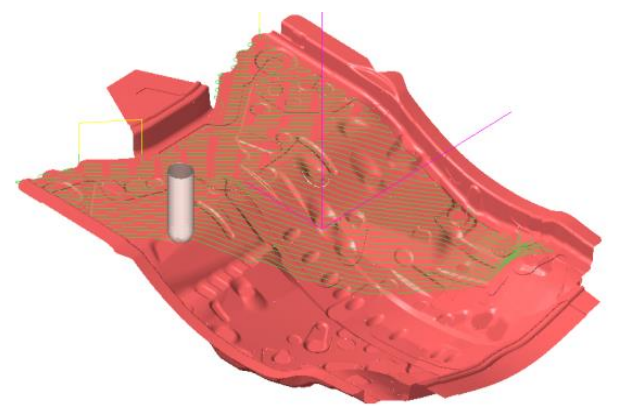

Figure 3. Raster

c. Pencil

Pencil still includes a 3 dimensional finishing program with target machining on the radius area to form a perfect face dies. Cutter used in pencil program with ball nose type cutter as seen Figure 4.

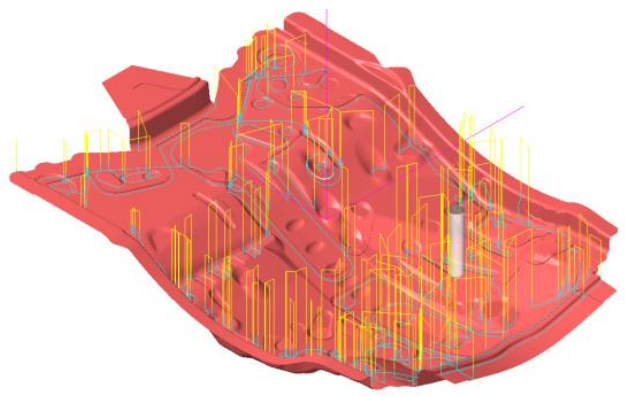

Figure 4. Clear

d. Profil/ Contour 2D

The profile is a program that runs alongside the curve line or profile area outside the 
controur dies, target machining creates a trimline path, and pol (pad opening line). Cutter used in Profile program with cutter type helical cutter and end mill as seen Figure 5.

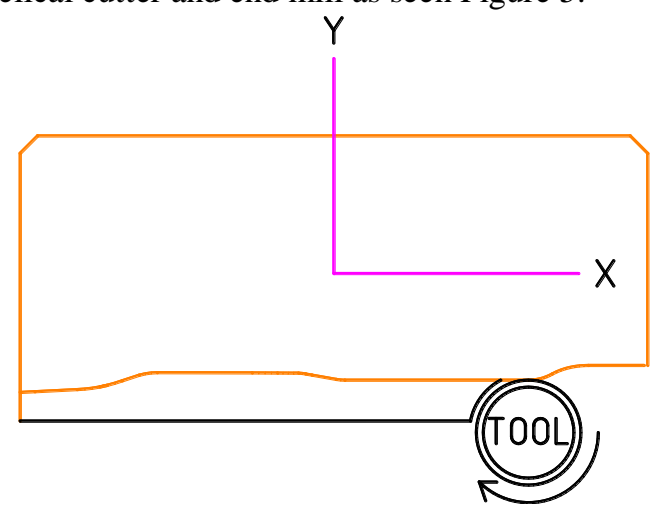

Figure 5. Profil

\section{Results and Discussion}

Machining pencil dies drawing program 53711/12 Machining Program to be analyzed that is the length of trajectory and machining time. The analysis focused on the type of machining program pencil cutter ball nose 10 generated from catia and mastercam because both machining the program when applied has a long enough trajectory and there is repetition on the same trajectory. This analysis was conducted with the aim of reducing machining time and will affect the cost of machining dies drawing 53711/12 as seen in Table 1 .

Table 1. Shows the amount of time on the machining program pencil diameter 10 produced by catia that is 5.55 hours. Table 2. Ie the total time data Machining pencil program $10 \mathrm{~mm}$ diameter resulting from mastercam with a track length of 256,760 meters and machining process time is 2.81 hours.

Numerical Control Code from CATIA as used analyst technique. Numerical control generated from identical CATIA runs with code G01 or Linear Interpolation Motion as seen in Figure 6.

Table 1. The Length of The Program Path from CATIA

\begin{tabular}{|c|l|l|c|c|}
\hline No & $\begin{array}{c}\text { Program } \\
\text { Name }\end{array}$ & Dimensi Cutter & M/ C Length (M) & $\begin{array}{c}\text { M/C Time } \\
(\mathrm{mnt})\end{array}$ \\
\hline 1 & P1101 & Ball Nose 10 & 180,994 & $02: 06: 16$ \\
\hline 2 & P2101 & Ball Nose 10 & 162,130 & $02: 24: 49$ \\
\hline 3 & P3101 & Ball Nose 10 & 54,147 & $01: 02: 18$ \\
\hline \multicolumn{2}{|c|}{ Total length/ time } & 397.271 & $05: 33: 23$ \\
\hline
\end{tabular}

Source : Nc Sheet PT. Mekar Armada Jaya

Table 2. The Length of Program Path from Mastercam

\begin{tabular}{|c|l|l|c|c|}
\hline No & $\begin{array}{c}\text { Program } \\
\text { Name }\end{array}$ & Dimensi Cutter & M/ C Length (M) & $\begin{array}{c}\text { M/C Time } \\
(\mathrm{mnt})\end{array}$ \\
\hline 1 & P1101 & Ball Nose 10 & 114,265 & $01: 06: 52$ \\
\hline 2 & P2101 & Ball Nose 10 & 119,26 & $01: 22: 07$ \\
\hline 3 & P3101 & Ball Nose 10 & 23,235 & $00: 19: 46$ \\
\hline \multicolumn{2}{|r|}{ Total length/ time } & 256,760 & $02: 48: 45$ \\
\hline
\end{tabular}

Source : Nc Sheet PT. Mekar Armada Jaya

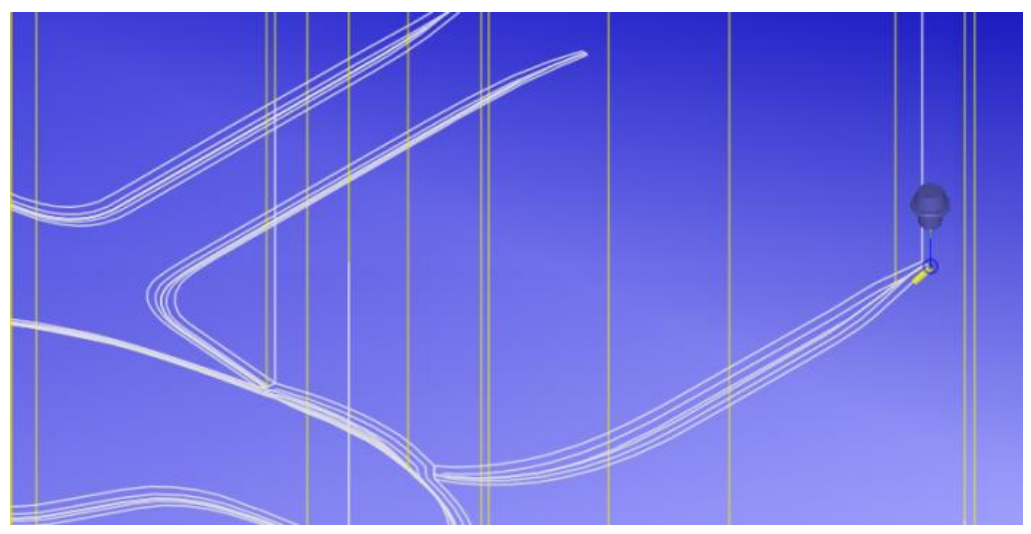

Figure 6. Numerical Control (CATIA) 


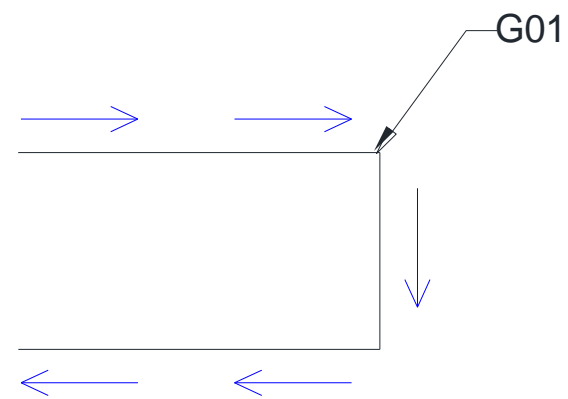

Figure 7. Code G01

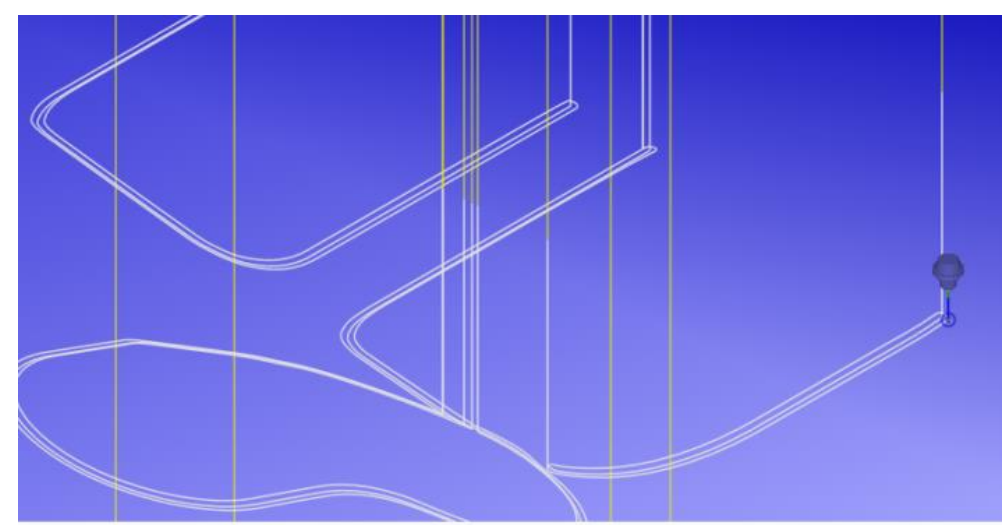

Figure 8. Numerical Control (Mastercam)

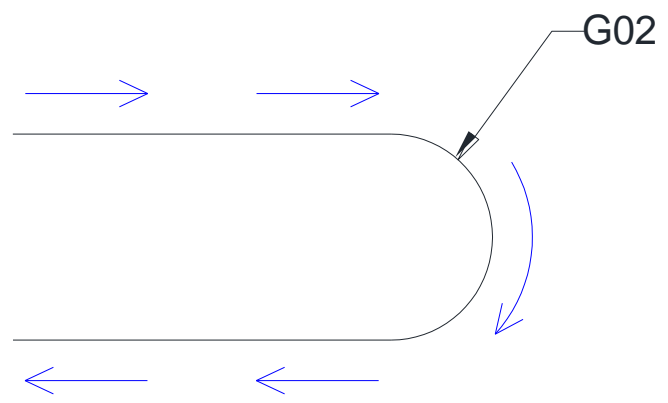

Figure 9. Code G02

Figure 7. Shows G01 motion during machining process of rotating direction. Numerical Control Code from Mastercam also used for analyst technique.

Numerical control generated from mastercam will run in accordance with the needs of drawing dies data that if the data dies flat face then appears G01 but in the area of radus and limid area / limit dies, the movement that appears $\mathrm{G} 02$ or G03 so bebean working machining machine becomes light.

The results of numerical control code comparison above the mastercam is favored because the workload of the engine becomes lighter and the machine aging machine is longer.

This analysis calculates the level of machining efficiency of a $10 \mathrm{~mm}$ cutter ball nose produced from mastercams, with comparable data using machining programs generated from catia software.

Efficency (technique/ physical $)=($ Output $) /$ (Input) x 100\%
Where,

$\mathrm{P}($ machining program from CATIA $)=05: 33: 23$ $=5.55$ hours

$\mathrm{Q}$ (machining program from Mastercam) = $02: 48: 45=2.81$ hours

Efficiency (technique/ physical)

$$
=\frac{P-Q}{P} \times 100 \%
$$

Efficiency (technique/ physical)

$$
=\frac{5.55-2.81}{5.55} \times 100 \%
$$

Efficiency (technique/ physical)

$$
=\frac{2.74}{5.55} \times 100 \%
$$

Efficiency (technique/ physical)

$$
=49.36 \%
$$

Percentage efficiency of machining program by using mastercam equal to $49,36 \%$. 


\section{Conclusions}

Machining program dies $640 \mathrm{~A}$ dies drawing $53711 / 12$ can be implemented from two software that is catia and mastercam.

Machining programs generated from mastermasters are more efficient because the numerical control (nc) that appears in accordance with the data of face dies (G01: flat data, G02 / G03: radius data) so as to affect the age of machine machining.

Percentage efficiency machining program generated from master camsebesar $49.36 \%$.

\section{References}

Budiman, A., Syarif, A., \& Isworo, H. (2014). Jurnal Ilmiah Teknik Mesin. 76 Universitas Lampung.

Masaya, T. (2011). Press Die Design Basic Text Book. Indonesia Mould \& Die Industry Association. Jakarta.
Mokh, s., \& Slamet, B. (1999). Sistem Manufaktur. Fakultas Teknologi Industri, Institut Sepuluh Nopember. Surabaya.

Nugroho, T. U., Saputro, H., \& Estriyanto, Y. (2012). Pengaruh Kecepatan Pemakanan dan Waktu Pemberian Pendingin terhadap Tingkat Keausan Cutter End Mill HSS Hasil Permesinan CNC Milling pada Baja ST 40. 79. Teknik Mesin UNS. Surakarta.

Santoso, J. (2013). Pekerjaan Mesin Perkakas. Kementerian Pendidikan \& Kebudayaan. Malang.

Tanshin, M. (2011). Press Die Design Basic Text Book. Indonesian Mold \& Die Industry Association. Jakarta.

Wignjosoebroto, S. (2006). Pengantar Teknik \& Manajemen Industri. Penerbit Guna Widya. Surabaya. 